\title{
PERSOALAN LIMITASI BUDAYA DAN SASTRA ISLAM
}

\section{Khalil}

Dosen Jurusan Bahasa dan Sastra Arab,

Fakultas Humaniora dan Budaya, Universitas Islam Negeri (UIN) Malang.

Jalan Gajayana No. 50 Telepon (0341) 570872, Faksimile (0341) 570872 Malang 65144

\begin{abstract}
The limitation of literature actually is still in discussion, on the other hand, it is fact that literature is the work produced by the cultural observer using language as his means. In addition to the limitation of literature, all of phenomena existing in certain society, certain period of time or certain situation are considered as literature. This point of view is not without any reasons, but it is based on the reality that literature is not independent, separated from it's society and culture which born and use it. It is clear that literature has position, role and function in society, and all of them always change from time to time and has differences among are society to another society.
\end{abstract}

Key words

Limitation, Literature, Culture, Islam

\section{Pendahuluan}

Bahwa sastra merupakan ekspresi estetis dengan menggunakan media bahasa berupa tulisan maupun lisan sebagai sarananya memang benar adanya. Sastra ada kalanya muncul sebagai respon balik berkat pengamatan seniman (budayawan) terhadap realitas empiris yang kemudian berusaha dimunculkannya kembali ke dalam "realitas fiktif" karyanya. Atau mugkin juga sastra itu lahir dari imajinasi kreatif seniman untuk menciptakan realitas nilai yang ia harapkan, baik 
terbatas pada karyanya saja maupun terimplementasi secara gradual pada lingkaran sosial, di mana sang seniman hidup .

Dari beberapa pandangan, sastra memang memiliki kekhasan yang mutlak yang menyangkut keindahan dan keartistikannya dibanding dengan karya seni lain. Suatu kekhasan yang bergerak pada dua sisi secara bersamaan, yaitu sisi fisik bahasa/ungkapan yang digunakan dan sisi makna yang dikandung dalam bahasa tersebut. Keindahan inilah yang mempengaruhi langgeng tidaknya suatu karya, atau luas tidaknya penerimaan di tengah khalayak pembaca atau para penikmat sastra.

Tulisan ini tidak dimaksudkan untuk mendiskusikan makna sastra, karena dalam hemat penulis, pengertian atau definisi sastra sudah sangat maklum, meskipun masih juga menyisakan perdebatan. Akan tetapi, hanya akan menyoroti sisi lain kesastraan yang selama ini masih dalam perdebatan juga, yaitu mengenai pendevinisian sastra Islam. Barangkali dua kata yang tersusun secara idlofy ini bagi sebagian orang tidak perlu dipersoalkan, karena sudah jelas maknanya sebagaimana jelasnya pengertian Islam itu sendiri. Namun demikian, simplikasi ini masih perlu dijabarkan lebih lanjut untuk mendapatkan keabsahan pengertian, sekalian untuk mendapatkan suatu makna yang bisa dipertanggungjawabkan secara teologis maupun sosial, karena memang sebenarnya pengertian sastra Islam tidaklah terbatas pada sastra yang mewartakan "alam langit" saja, juga tidak pada karya yang dimunculkan dari seorang budayawan muslim dengan memakai idiomidiom keislaman saja, juga bukan terbatas kelahirannya dari wilayah yang penduduknya muslim, tapi lebih dari itu.

Dua masalah yang akan menjadi bahan pembicaraan pada tulisan ini, yaitu mengenai Budaya Islam dan Sastra Islam. Budaya perlu dielaborasi, karena ia merupakan élan vital seniman (sastrawan) yang sekaligus sebagai pedoman dia dalam berkarya. Sebab, tidak mungkin seorang seniman memulai dari "ruang hampa", juga tidak mungkin ia mengakhiri karyanya dengan kehampaan. Atau secara filosofis, mungkin saja seseorang tidak tahu kenapa dia (tiba-tiba) berada di 
suatu tempat, tapi ia mesti tahu alasan kenapa dia pergi atau bertahan di tempat di mana ia berada saat ini. (teleologis).

\section{Limitasi Budaya Islam}

Apa dan Bagaimana Budaya Islam itu? Pertanyaan ini tidak gampang ditemukan jawabannya, sama tidak gampangnya bagi kaun idealis ketika ditanya apa Islam atau muslim itu? Sulit menjawab di tengah hamparan budaya yang hampir tak teridentifikasi secara jelas, dan di tengah lingkungan kehidupan yang penghuninya telah pandai membuat batas antara nilai etik-formalis (verbalistik) dengan amalpraktis sosialnya. Apalagi bila mengingat sebuah ucapan yang konon dilontarkan oleh seorang tokoh muslim, Muhammad Abduh, ketika kembali dari kunjungannya ke negara-negara Eropa. Sang tokoh berkata bahwa di negeri-negeri yang dikunjungi itu ia menemukan Islam, meskipun tidak ada kaum muslim, sedangkan di negeri yang ia tempati, dengan warga penduduk mayoritas beragama Islam, ia tidak menemukan Islam. Dari sini bisa dipetik suatu kesimpulan bahwa Islam itu terkadang berbeda jauh dengan tampilan muslim. Nilai Islam tidak mesti menjadi watak seorang muslim, dan ini fakta yang sering ditemukan akhir-akhir ini di banyak wilayah yang warganya secara formal mengaku sebagai muslim.

Kebudayaan dalam konteks etika adalah kebudayaan dalam artinya sebagai kata kerja atau kebudayaan sebagi proses, bukan sebagai kata benda atau produk. Kebudayaan sebagai proses berpusat pada pikiran dan hati manusia. Oleh karena itu kebudayaan bisa juga disebut sebagai aktivitas pemikiran. Dalam pengertian yang demikian, kebudayaan adalah usaha dan upaya manusia menjawab tantangan yang dihadapkan kepadanya. Tantangan yang dihadapi manusia makin hari makin kompleks, sehingga kebudayaan juga menampilkan wajahnya yang penuh komplesitas.

Pada dataran ontologis, kebudayaan ada karena adanya manusia yang bersumber pada pikiran, hati dan perasaannya. Oleh karena itu, pada dataran fungsional, manusia itu sendiri terjaring dalam rajutan 
kebudayaan tersebut, bahkan bisa jadi manusia itu ditentukan oleh jaring rajutan itu, bukan menentukan dalam artian yang aktif. Pada kondisi demikian, manusia dipaksa mengikuti pola dan sistem kebudayaan yang ada, ia tidak berdaya untuk melepaskan diri, sehingga ia tidak lagi memiliki kebebasan yang menjadi fithrahnya. Fenomena yang muncul kemudian adalah manusia mengalami alienasi diri; terasing, kesepian dan gelisah (Asy'ari, 2002:115)

Di dalam Islam, dikenal adanya konsep tauhid, yaitu suatu konsep sentral yang berisi ajaran bahwa Tuhan adalah pusat dari segala sesuatu, dan bahwa manusia sebagai hamba harus mengabdikan diri sepenuhnya kepada-Nya. Konsep tauhid ini mengandung implikasi doktrinal lebih jauh bahwa tujuan kehidupan manusia tidak lain hanyalah menyembah kepada-Nya. Doktrin bahwa hidup harus diorientasikan untuk pengabdian kepada Allah ini merupakan kunci dari seluruh ajaran Islam. Dengan demikian, di dalam Islam, konsep mengenai kehidupan adalah konsep yang teosentris, yaitu bahwa seluruh kehidupan berpusat kepada Tuhan. (QS. al-An'am: 103 dan QS. Al-A'raf:53)

Tetapi kemudian, sistem tauhid ini ternyata juga mempunyai konsekuensi lain yang seolah merupakan kebalikan dari "al-ibadah li Allah". Di dalam al-Qur'an, banyak sekali ditemukan ayat yang mengatakan bahwa iman, yaitu keyakinan religius yang berakar pada pandangan teosentris itu selalu dikaitkan dengan amal shalih. Iman dan amal merupakan suatu kesatuan yang tidak boleh dipisah-pisahkan. Ini menunjukkan bahwa iman harus selalu diaktualisasikan menjadi amal ; bahwa konsep tentang iman, tentang tauhid harus diaktualisasikan secara konkrit menjadi aksi kemanusiaan, adalah fakta yang tidak bisa dibantah. Perintah tentang zakat misalnya, pada ujungnya adalah untuk terwujudnya kesejahteraan sosial. Juga perintah penegakan, atau sekedar pelaksanaan ibadah shalat, idealnya dapat mencegah dari tindakan nista dan kemunkaran. Dengan demikian, di dalam Islam, konsep teosentrisme ternyata bersifat humanistic. Artinya, manusia, dalam segala aktivitasnya harus dapat memusatkan diri kepada Tuhan, tetapi tujuannya tidak lain adalah untuk kepentingan manusia sendiri. 
Humanisme-teosentris inilah yang merupakan nilai inti (core-value) dari seluruh aktivitas muslim, termasuk dalam aktivitas budayanya atau berkesenian.

Humanisme-teosentris kemudian menjadi tema sentral budaya Islam. Dari tema sentral ini muncul sistem simbol, yaitu sistem yang terbentuk karena proses dialektik antara nilai dan tradisi. Misalnya, di dalam al-Qur'an ada rumusan amr ma'ruf nahi munkar, yaitu suatu perintah untuk menyeru kepada kebajikan dan mencegah kemunkaran. Dari rumusan ini ada dua proses yang berlawana tapi sekaligus merupakan suatu kesatuan. Kuntowijoyo menyebutnya proses ini sebagai emansipasi dan pembebasan. Amr ma'ruf diarahkan untuk mengemansipasikan manusia kepada nur, kepada cahaya petunjuk Ilahi, untuk mencapai kepada fithrah. Fithrah ini adalah keadaan di mana manusia mendapatkan posisinya sebagai makhluk yang mulia. Sementara itu nahi munkar, atau mencegah kemunkaran merupakan langkah berangkai dari gerakan amr ma'ruf, berarti membebaskan manusia dari segala belenggu kegelapan dalam pelbagai manifestasinya. Dalam bahasa ilmu sosial, meminjam istilah Kuntowijoyo, disebutnya pembebasan dari kebodohan, kemiskinan, ataupun penindasan. (Kuntowijoyo, 1998:229)

Islam memang bukan merupakan suatu ajaran berpikir dan bertindak yang didikte oleh teologi an sich, karena itu, di dalam struktur kegamaan Islam, tidak dikenal dikhotomi antara domain duniawi dan domain ukhrawi (sekularisme). Konsep agama dalam Islam tidak semata-mata teologi, sehingga serba pemikiran teologis bukanlah karakter Islam. Nilai-nilai yang diajarkan Islam pada dasarnya bersifat meliputi bagi penataan sistem kehidupan sosial, politik, ekonomi, dan budaya. Oleh karena itu, tugas terbesar dari Islam adalah melakukan transformasi sosial dan budaya dengan nilai-nilai itu.

Islam adalah sebuah humanisme, yaitu agama yang mementingkan manusia sebagai tujuan sentral (antropomorphis). Inilah nilai dasar Islam. Tetapi perlu dipahami, bahwa humanisme dalam Islam berbeda dengan prinsip-prinsip yang ada dalam filsafat atau 
mungkin yang ada dalam agama lain, humanisme Islam adalah humanisme teosentris. Artinya, ia memusatkan ajarannya pada keimanan terhadap Tuhan, namun keimanan itu yang mengarahkan perjuangan umatnya untuk kemuliaan peradaban manusia. Prinsip humaisme teosentrik inilah yang kemudian akan ditransformasikan sebagai nilai yang dihayati dan dilaksanakan sepenuhnya dalam kehidupan bermasyarakat dan berkebudayaan.

Salah satu dari implementasi nilai budaya Islam itu adalah cara berpikir rasional yang merupakan bagian sah dari epistimologi Islam (Asy'ari, 2002:72). Dalam sejarah dikenal bahwa ilmu-ilmu rasional merupakan bagian dari kebudayaan Islam jauh sebelum dunia Barat mengenal rasionalisme. Ilmu manthiq, falak, hukum Islam (fiqh) dan sebagainya merupakan produk dari epistimologi ini. Di Barat, rasio telah melahirkan perkembangan ilmu-ilmu eksakt yang pada gilirannya ilmu-ilmu itu mendasari kebangkitan ilmu pengetahuan pada abad ke17. Tapi sesungguhnya perkembangan ilmu yang berimbas pada kemajuan kebudayaan itu karena meminjam epistimologi Islam.

Oleh karena itu, sesungguhnya tidak ada alasan untuk mencemaskan pemikiran rasionalisme, atau pada pemikiran empirisme yang melanda dunia Islam saat ini, kecuali jika tidak ada keyakinan adanya integrasi antara ilmu pengetahuan dengan nilai-nilai yang inklusif dari Islam. Persoalannya sekarang adalah bagaimana umat dapat melakukan transformasi nilai-nilai Islam itu pada zaman yang sering disebut sebagai era komunikasi global dan era abstrak (jangan sampai era edan). Strategi bagaimanakah yang dapat dilakukan untuk mengadakan transformasi dalam masyarakat seperti itu.

Untuk menjawab tantangan ini, ada beberapa tawaran yang agaknya perlu diperhatikan. Bila menengok ajaran Islam, pada dasarnya seluruh kandungan nilainya bersifat normatif, maka ada dua cara agar nilai normatif itu menjadi operasional dalam kehidupan yang nyata. Pertama nilai-nilai normatif itu diaktualkan langsung menjadi perilaku sosial. Untuk jenis aktualisasi semacam ini contohnya adalah seruan moral praktis al-Qur'an, misalnya, perilaku adil dalam kepemimpinan, 
ramah dalam sikap, loman atas karunia. Seruan ini langsung dapat diterjemahkan ke dalam praktek, ke dalam perilaku sehari-hari.

Adapun cara yang kedua adalah mentransformasikan nilai-nilai normatif itu menjadi sebuah teori ilmu sebelum diaktualisasikan ke dalam perilaku. Dan sepertinya, cara yang kedua ini lebih relevan pada situasi sekarang ini. Namun demikian, cara ini membutuhkan beberapa fase formulasi yang relatif susah: teologi-filsafat sosial-teori sosialperubahan sosial. Tanpa melakukan apa-apa, mustahil terjadi transformasi budaya seperti yang Islam harapkan. (Kuntowijoyo, 1998:170)

Konsep normatif agama mengenai budaya tidak saja mencoba memahami, melukiskan, dan mengakui keunikan-keunikannya, tetapi agama juga mempunyai konsep pembenahan (perintah) dan tanggungjawab, Ilmu menjadikan budaya sebagai sasaran pemahaman, sedangkan agama memandang budaya sebagai sasaran pembinaan. Masalah budaya bukanlah masalah bagaimana kita memahami, tetapi bagaimana mengubah. Sikap agama ini kiranya tidak banyak berbeda dengan sikap ilmu atau filsafat, yang semuanya ingin mengubahnya sesuai dengan kondisi idealnya, yaitu wujud budaya yang sempurna. Ilmu yang berorientasi pada perubahan itu mengalami metamorfosa menjadi ideologi. Dalam pengertian ini, Islam bias juga merupakan ideologi.

Dalam ilmu dan agama, konsep mengenai arah dan tujuan kehidupan manusia menempati posisi sentral dalam mempertimbangkan budaya. Dalam antropologi budaya misalnya, pendekatan evolusi akan sampai pada penggambaran tiap-tiap kurun budaya tertentu. Dan karena konsep evolusi menghendaki bahwa budaya itu mengalami kemajuan terus-menerus, maka diperlukan ukuran untuk kemajuan tersebut. Dalam Islam, konsep evolusi budaya itu diarahkan untuk perkembangan menuju falah melalui proses tazkiyah. Dengan demikian, Islam mempunyai ukuran-ukuran sendiri untuk melihat perkembangan budaya manusia. 
Lebih lanjut tentang budaya dalam konsep Islam, prosesprosesnya tidak boleh dilepaskan dari nilai-nilai etika, karena budaya itu merupakan eksistensi hidup manusia sendiri yang terbingkai dalam nilai-nilai etika. Sejak dari berpikir, berimajinasi dan mengaktualkan diri dalam pilihan-pilihan serta eksperimentasi sosial yang kreatif sudah seharusnya didasarkan pada nilai-nilai yang baik untuk menciptakan kehidupan yang lebih manusiawi, penuh dinamika yang memperkaya rohani, bukan untuk aktualisasi yang merefleksikan pemenuhan kepuasan nafsu-materialisme. (QS. Al-Jaatsiyah:23)

Dalam tahapan demikian, proses kebudayaan merupakan proses lanjutan yang juga bias disebut tiruan dari kekuatan samawi dalam proses penciptaan alam semesta, sehingga terjadi keseimbangan antara alam semesta ciptaan Tuhan dengan alam budaya ciptaan manusia. Dengan demikian, kebudayaan menjadi suatu bentuk proses kerjasama kreatif antara manusia dengan wahyu ketuhanan. Jika Tuhan menciptakan lautan manusia membuat kapal untuk mengarunginya, jika Tuhan menciptakan malam, manusia meneranginya dengan lampulampu temaram yang romantik. Pada tahapan itu, proses kebudayaan merupakan amal saleh dan menjadi bentuk perjumpaaan kreatif antara manusia dengan Tuhan. Allah SWT berfirman (yang artinya), "Siapa yang mengharapkan perjumpaan dengan Tuhannya, maka hendaklah ia mengerjakan pekerjaan yang baik, dan janganlah mempersekutukan Tuhannya dengan siapapun". (QS. Al-Kahf:110)

Bagaimana kemudian tugas budayawan dalam kancah budaya saat ini? Secara ideal, tugasnya adalah mengarahkan gerak langkah kehidupan (budaya) manusia menuju falah, yaitu kebahagiaan dan keberuntungan yang mesti dicapai oleh setiap manusia. Lebih-lebih seorang muslim, konsep iman dan amal shalih yang bergerak secara bersamaan dalam dua arah; perintah ma'ruf dan mencegah munkar adalah sesuatu yang tidak boleh diabaikan dalam berkarya.

\section{Limitasi Sastra Islam}


Sastra adalah buah karya yang diproduksi kaum budayawan dengan mempergunakan bahasa sebagai kendaraannya. Sebagai kendaraan, ia bisa saja dimuati oleh sang budayawan dengan berbagai jenis muatan yang terhimpun dalam kantong ontologisnya; dimensi sosial, politik, ekonomi budaya, spiritualitas dan lain sebagainya. Muatan-muatan itu bisa menjelma dalam wujud kasar yang setiap penikmat sastra dapat mengetahui dan merasakan, namun bisa juga dalam wujud yang amat halus dan lunak, di mana tidak sembarang orang dapat mengetahui dan merasakannya.

Sastra Islam dalam hal ini, sangat mungkin setiap orang memiliki bayangan makna yang berbeda-beda. Sebagian mengartikan karya sastra yang penuh dengan tampilan ayat-ayat verbal yang dinukil dari al-Qur,an maupun al-Hadits. Sebagian lagi mengartikan yang dihasilkan dari seorang budayawan muslim, tanpa mengamati lebih jauh tentang makna dan isi yang terkandung sebagai wujud implisit jawaban pertanyaan kenapa karya itu ditulis. Atau bahkan ada yang memberikan batasan pada sebuah karya yang terbit di dunia Islam.

Memang dalam paradigma Islam, konsep baku tentang sastra dalam perspektif Islam belum ada kesepakatan penuh. Ada sinyalemen, belum matangnya paradigma sastra dalam Islam dikarenakan adanya perdebatan dan kontroversi yang belum pernah tuntas yang disebabkan oleh beberapa faktor. Faktor yang sangat menonjol dalam hal ini adanya beberapa ayat al-Qur'an dan Hadits Nabi yang ditafsirkan secara apa adanya sebagai bukti kekurang-simpatisan Islam terhadap seni sastra. (QS. Al-Syu'ara 224-227)

Sebagian orang menjadikan ayat al-Qur'an dan Hadits maupun aqwal Arab yang kurang simpati tersebut sebagai bukti tidak adanya apresiasi Islam terhadap sastra. Sebenarnya, bila dipahami secara obyektif, keterkaitan dan keterlibatan al-Qur'an dengan sastra tidak dapat dipungkiri, dan perlu diketahui bahwa keterlibatan itu bukanlah dalam hubungan yang kontraproduktif, melainkan hanya menjelaskan sebagai bukti bahwa nilai kesastraan al-Qur'an amatlah luar biasa dibandingkan dengan kehebatan sastra Arab. Ayat-ayat tentang syair 
dalam al-Qur'an tidak lain sebagai penolakan kepenyaiaran Nabi Muhammad yang mengemban amanat samawi. Dengan bahasa lain menghindari image kaum musyrik Arab bahwa Muhammad adalah penyair, atau manusia yang sedang trance karena terkena sihir yang ditimbulkan oleh masuknya roh halus ke dalam tubuhnya. (Kholis, 2005:102)

Sebenarnya usaha yang mengarah pada penjustifikasian atau penanaman nilai Islam pada berbagai aspek telah lama dilakukan. Hal itu terjadi juga pada bidang Bahasa Arab dan bahasa-bahasa lain di dunia Islam. Demikian juga sudah dilakukan pada Sastra Arab pada jaman Nabi. Dalam hal ini Najib Kailani menegaskan bahwa para penyair di jaman Nabi sudah terbiasa menyelipkan nilai-nilai Islam dalam karyanya dan Nabi turut mendukung hal tersebut. Para penyair itu juga bersenandung tentang peristiwa-peristiwa sejarah Islam sembari menampik dan menolak celaan lawan terhadap Islam. Dengan begitu pada syair-syairnya sudah tidak terdapat warisan jahiliyah semacam fanatisme kesukuan, ratapan-ratapan ataupun kebanggaan akan keturunan, sebab sudah diganti dengan nilai-nilai luhur Islam. (Kailani; 1985:70)

Adapun pada masa sekarang, sastra tampaknya sudah dapat ditempatkan pada posisinya yang proporsional. Sastra di kalangan umat Islam sudah agak lama menjadi konsumsi sehari-hari bagi keperluan dakwah. Keterlibatan ulama dalam dunia kesastraan juga bukan merupakan fenomena baru. Gendhing-gendhing Jawa semacam Tombo Ati, Ilir-ilir, dan Sluku Bathok adalah karya seni sastra yang bercitra rasa islami. Pada era modern di Indenesia, kita juga mengenal Haji Abdul Karim Amrullah (HAMKA) ulama kharismatik yang pernah menjabat ketua Muhammadiyah juga sebagai seorang sastrawan. Selain itu, kita juga mengenal KH. Musthafa Bisri yang telah banyak melahirkan karyakarya sastra. Kitapun bisa menyebut sederetan nama dari kharij yang membawa cita rasa islam dalam karyanya, seperti : Musthafa Luthfi alManfaluti, Najib Kailani, Najib Mahfud, Nawal Sadawi dan lain sebagainya. 
Dengan demikian, kehadiran sastra di dunia Islam tidak perlu diperdebatkan lagi. Namun masih ada sisa pertanyaan yang belum terjawab, "Apa dan bagaimana sastra Islam itu sebenarnya? Taufik Ismail memberi jawaban, sastra Islam adalah sastra dzikir, yaitu sastra yang mengingatkan pembacanya pada sang Maha pencipta. Adapun Abdul Hadi WM memberi jawaban, sastra Islam adalah sastra yang berorientasi tauhid atau memiliki tujuan transcendental. Sementara itu, Simuh, guru besar UIN Jogjakarta yang banyak bergelut dengan warisan Ronggowarsito turut sumbang pemikiran atas polemik tentang sastra Islam dengan memperkenalkan sastra Islam progresif, yaitu sastra yang memberi pencerahan dan membawa semangat ijtihad. Dengan bahasa lain, memberi spirit tranformasi sosial.

Dalam konteks pendevinisian ini, kita harus bisa membuang jauh-jauh aktivitas sensor atas sastra keagamaan secara sempit dan dogmatik yang menganggap agama hanya serangkaian atauran, hukum, perintah dan larangan-larangan yang bersifat mutlak. Karena aktivitas semacam itu hanya akan melahirkan buku indeks, yaitu daftar karyakarya sastra terlarang. Bagi mereka yang mengembangkan buku indeks itu, sastra hanyalah merupakan polesan atau make up rias bagi formulaformula kegamaan. Model kerja yang demikian jelas akan mempersempit gerak langkah agama sebagai landasan etik dan moral. Di samping itu juga akan memasung kreativitas berkesenian bagi siapa saja yang ingin "mengajak" kepada tatanan sosial yang dipenuhi nilai etika dan moralitas.

Oleh karena itu, untuk menghindari perdebatan lebih panjang, dan untuk melempangkan jalan yang lebih luas bagi sastra Islam, Kuntowijoyo memberi alternatif penamaan baru untuk menghindari keterjebakan pada batas ideologi, ia menyebutnya sastra profetik. Sastra profetik bagi Kuntowijoyo dipandang sebagai wadah yang sanggup menampung berbagai permasalahan kehidupan yang dipenuhi dengan semangat kenabian sebagai pilar utamanya.

Sastra Islam dalam konsep profetik Kunto ini sepenuhnya mengacu pada sebuah ayat yang artinya ; kalian adalah umat terbaik yang 
dlaihairkan untuk manusia. Dilahirkan supaya menyeru kepada amal kebaikan dan mencegah perbuatan munkar.dan supaya kalian beriman kepada Allah. (QS. Ali Imran:110) Dengan demikian, ada 3 (tiga) landasan pokok yang menjadi pijakan sastra prophetik ini. Pertama, menyuruh kepada kebaikan (ma'ruf) yang oleh Kuntowijoyo dibahasakan dengan humanisasi. Dalam konteks pemahaman Islam, humanisasi tak lain adalah pemuliaan manusia dengan cara meletakkannya dalam posisi yang mulia dan terpuji. Mulia di hadapan Tuhannya karena segala tindakan berlandaskan ketaqwaan, dan terpuji di tengah kehidupan masyarakat karena tidak menebar nista.

Pemuliaan manusia perlu, karena peradaban modern cenderung merendahkan derajat manusia melalui berbagai jalan; teknologi, pasar, bahkan juga oleh negara dengan berbagai instrumen dan institusinya. Dalam situasi yang direndahkan itu, sebuah karya sastra yang melukiskan kedamaian berkat adanya keharmonisan akan mengangkat kembali manusia yang tidak pernah damai dan harmonis dengan lingkungannya.

Landasan kedua dari sastra Islam adalah Mencegah kemunkaran atau liberasi. Liberasi dalam konsep Kunto ini adalah pembebasan diri. Timbul pertanyaan kemudian, "Apa yang perlu dibebaskan dari kehidupan manusia ini?". Pembebasan yang dimaksud adalah pembebasan dari segala macam kekejian, atau pembebasan dari bentuk-bentuk pembelengguan spirit insaniyah yang bisa menyeret kepada naluri-naluri tak terpuji, naluri kebinatangan.

Pembebasan ini perlu karena dalam peradaban modern saat ini manusia telah menjadi budak-budak yang dipaksa mengabdi kepada mesin-mesin atau sistem sosial tertentu. Dalam situasi yang demikian, hasil karya sastra yang menceritakan perjuangan seorang anak manusia yang melawan penindasan orang-orang kuat semisal para pemilik modal atau para penguasa adalah termasuk dalam jenis ini.

Sastra sebagai pengalaman estetik pada tahap yang spiritual, pada hakikatnya merupakan proses pembebasan dan peneguhan eksistensi kemanusiaan. Pembebasan dari tekanan dan dorongan- 
dorongan tubuh luar yang cenderung mengabdi kepada kepuasankepuasan fisik semata. Sastra merupakan peneguhan kemanusiaan, yaitu memperkuat kepduliannya yang tinggi, dengan menegaskan keberpihakannya pada nilai-nilai kemanusiaan. (Musa; 2002:138)

Landasan ketiga, sebagai manifestasi keimanan, sastra Islam sudah semestinya mencerminkan transendensi, karena dunia modern yang kita rasakan saat ini cenderung melakukan desakralisasi dan sekularisasi sebagai akibat materialisme. Dalam hal ini transendensi bukan hanya kesadaran ketuhanan yang terbatas pada kepercayaan agama, namun lebih dari itu, yang mampu melampaui batas kemanusiaan itu sendiri. Dari sudut pandang yang demikian, maka sebuah narasi yang menggambarkan ketimpangan sosial adalah perlawanan terhadap ketidak-adilan, yang menyiratkan pesan toleransi adalah nasihat bagi yang ingin menang dan benar sendiri, dan yang menyerukan orang untuk beribadah (mahdo wa ghairu mahdo) adalah perlawanan terhadap dunia yang materialistik.

Tiga pilar sebagai landasan sastra Islam di atas tidak mesti muncul mencolok dalam karya sastra, akan tetapi bisa menjelma sebagai spirit nilai sastra yang mendorong penikmatnya kepada hal-hal yang terpuji, tidak mencelakakan, dan memanusiakan sesama.

Dengan spirit semacam itu, sastra Islam, atau yang lebih tepat sastra yang bernilai Islam tidak akan terkungkung pada terminologi atau bangunan keagamaan Islam semata, tapi juga bisa menerobos berbagai simbol dan pagar agama-agama serta kesadaran relijius manapun di luar ruang-ruang keagamaan. Sastra Islam adalah rahmah lil alamin yang senantiasa memiliki nilai universal dan kontekstual di manapun dan kapanpun juga.

\section{Penutup}

Perlu disadari bahwa dunia yang kita tempati saat ini berada dalam kondisi yang disebut masyarakat abstrak. Pada kondisi sebelumnya, orang hidup dalam masyarakat yang konkrit, nyata. Dalam masyarakat konkrit itu, hubungan terjadi secara individual orang 
dengan orang, dan hubungan tersebut berlangsung dari muka ke muka. Tetapi kini, hubungan seperti itu sudah hilang ketika masyarakat berada pada kondisi yang abstrak. Pada masyarakat abstrak ini yang menentukan dan mengatur bukan lagi orang secara personal, tetapi sistem. Karakteristik perorangan seperti akhlak, keimanan, emosi, dan kepentingan harus berusaha menyesuaikan diri dengan sistem yang ada, karena situasi global masyarakat (birokrasi dan pasar) sangat bergantung pada kualifikasi objektif, bukan pada kualifikasi subjektif. (Kunto; 2001:27)

Dalam persoalan dakwah dan komunikasi agama sebagai amanah yang diemban setiap orang beriman juga bergantung pada sistem yang abstrak dan objektif tersebut. Oleh karena itu, orang harus memperhatikan komunikasi abstrak lewat simbol-simbol budaya supaya dakwahnya berhasil. Komunikasi ini memang tidak terjadi secara berhadapan langsung orang-perorang, tapi akan memberikan rasa bangga tersendiri bagi orang beriman (muslim). Demikian juga akan mencegah orang untuk menjadi murtad dan kafir. Akan tetapi kebanyakan orang tidak yakin bahwa mereka telah berbuat untuk agama dengan aktivitas yang bergerak di dunia yang simbolis ini. Hal itu dikarenakan gambaran masyarakat yang ada dalam benaknya adalah masyarakat konkrit, sehingga segalanya harus eksplisit dan kentara. Iman itu mengikuti aturan Islam, sementara Islam itu juga jelas dengan "mengikuti" lantunan verbal ayat-ayat Qur'an dan Hadits, bukan ruh dan spiritualnya.

Padahal, makin modern suatu masyarakat makin abstrak masyarakat itu. Karena itu, jangan pernah melupakan simbol-simbol budaya untuk "mengislamkan" pemikiran, ilmu pengetahuan, dan juga seni. Lalu, apakah dalam rangka berdakwah dengan media sastra misalnya, setiap budayawan muslim harus secara eksplisit berbajukan "keislaman"? Jawabannya tergantung pemahaman sang budayawan tersebut terhadap arti kata "bijaksana" (al-hikmah). $\square$ 


\section{DAFTAR PUSTAKA}

Ambary, Hasan Muarif. 1998. Menemukan Peradaban Islam. Jakarta: Logos Wacana Ilmu.

Asy'ari, Musa. 2002. Filsafat Islam Sunnah Nabi dalam Berpikir. Yogyakarta: LESFI.

Faruk, H.T. 2001. Beyond Imagination: Sastra Mutakhir dan Ideologi. Yogyakarta: Gama Media. 
Hadi, Abdul W.M. 1985. Sastra Sufi Sebuah Antologi. Jakarta: Pustaka Firdaus.

Hardjana, Andre. 1994. Kritik Sastra Sebuah Pengantar. Jakarta: Gramedia Pustaka Utama.

Kailani, Najib. 1985. Rihlah ma'a al-Adab al-Islami. Beirut: Muassasah alRisalah.

Khalafullah, Muhammad A. 2002. Al-Qur'an Bukan Kitab Sejarah : Seni, sastra, dan Moralitas dalam Kisah-kisah al-Qur'an. Terj. Zuhairi Misrawi dan Anas maftukhin. Jakarta: Paramadina.

Kuntowijoyo. 1998. Paradigma Islam. Bandung: Mizan.

2001. Muslim Tanpa Masjid. Yogyakarta: Mizan.

Qutub, Muhammad. 1987. Manhaj al-Fan al-Islami. Kairo: Dar al-Syuruq.

Setiawan, M. Nur Kholis. 2005. Al-Qur'an Kitan Sastra Terbesar. Yogyakarta: El-Saq Press.

Shadily, Hasan dkk. 1983. Ensiklopedi Indonesia. Jakarta: Ichtiar BaruVan Hoeve. 